\title{
FELLOW CUSTOMERS AS A SOURCE OF UNFRIENDLINESS: THE ROLE OF DESCRIPTIVE NORMS IN DEVIANT CUSTOMER BEHAVIOR
}

Arne K. Albrecht, Friedrich-Schiller-University of Jena, Germany Gianfranco Walsh, Friedrich-Schiller-University of Jena, Germany Simon Brach, Friedrich-Schiller-University of Jena, Germany

\begin{abstract}
This research investigates how customers influence one another in the servicescape, as well as how this influence affects deviant behavior toward service employees. Drawing on social norm and social identity theories, the authors hypothesize that the appropriateness of fellow customers' behavior predicts customers' friendliness toward employees, as long as fellow customers appear similar to the self. The hypotheses tests use data obtained from a sample of more than 200 shoppers. By applying multivariate regression and moderator analyses, the authors determine that fellow customers serve as critical antecedents of deviant behavior. If customers perceive fellow customers' behavior as inappropriate, they are less friendly toward service employees, but only when those customers perceive their fellow customers as similar to themselves. These results have theoretical and practical implications within a social norm framework.
\end{abstract}

References available upon request 